Iran Journal of Nursing (IJN)

Vol 33, No. 126, Oct 2020: 103- 116

\title{
The Correlation of Missed Nursing Care and Perceived Supervisory Support in Nurses
}

\author{
Ilnaz Vatankhah ${ }^{1}$, Monireh Rezaei ${ }^{2}$, Esfandiar Baljani ${ }^{3}$
}

\begin{abstract}
Background \& Aims: Missed nursing care is a common threat to the safety and quality of patient care, and investigating the influential factors in this regard could prevent or minimize this issue. Missed nursing care could lead to patient readmission and extra costs imposed on patients and healthcare organizations. Supervisor support plays a pivotal role in the commitment of nurses to the organization. The behaviors and activities of health supervisors could promote the positive attitude of the subordinates, thereby leading to their moral commitment. Although missed nursing care is considered to be a highly challenging issue for nursing managers, few studies have evaluated perceived care support and the associated challenges. The present study aimed to investigate the correlation between missing nursing care and perceived supervisory support.

Materials \& Methods: This descriptive-correlatinal study was conducted on 139 nurses employed in the inpatient wards of Imam Reza Hospital in Urmia, Iran during May-March 2019. The participants were selected via census sampling. Data were collected using a questionnaire, the first section of which consisted of demographic data, the second section was the missed care nursing questionnaire, and the third section included the standard tools for the assessment of perceived supervisory support. The missed care questionnaire was designed and psychoanalyzed by Kalish in 2006, and the items are scored based on a five-point Likert scale (Never=0, Always=4). The scale has four domains of review, interventions and personal care, interventions and primary care, and planning. The family supportive supervisor behaviors (FSSB) perceived support questionnaire consists of 14 items and was designed and psychoanalyzed by Hammer in 2009. The questionnaire items are scored based on a five-point Likert scale, with the higher scores indicating higher parental support. The main dimensions of the FSSB are emotional support, instrumental support, and role models. After obtaining the required permit for sampling, the questionnaire was distributed among the nurses working in different shifts and on different days. With their consent, the contact number of the participants was obtained. The questionnaires were collected from the respondents in the same or the next work shift and with proper coordination. The inclusion criteria were having a bachelor's degree (or higher), informed consent to participate in the research, employment in the hospital as a nurse, and minimum work experience of six months. Data analysis was performed in SPSS version 16 using descriptive statistics (mean and standard deviation), Pearson's correlation-coefficient, independent t-test, and the analysis of variance (ANOVA) at the significance level of $\mathrm{P}<0.05$.

Results: The highest mean scores of perceived supervisory support achieved by the nurses were in the items regarding time allocation to listening to the problems of nurses, listening to the problems of nurses about work difficulties and unemployment, creativity in task assignment to improve teamwork in the ward, ward management to meet the needs of each nurse separately, and welcoming suggestions to facilitate the balance of the professional and routine needs of nurses. The most significant aspects of missed nursing care were helping patients in the toilet within less than five minutes after the patient's request, meal preparation for the patients who are able to eat without help, changing patients' position every two hours, and the oral care (mouthwash use), skin care, and bathing of patients. Pearson's correlation-coefficient indicated a significant, weak, inverse correlation between the
\end{abstract}

\footnotetext{
1. Department of Nursing, Islamic Azad University, Urmia Branch, Urmia, Iran

2. Department of Midwifery, Islamic Azad University, Urmia Branch, Urmia, Iran Tel: $09144419489 \quad$ Email: m.rezaei@iaurmia.ac.ir

3. Department of Nursing, Islamic Azad University, Urmia Branch, Urmia, Iran
}

(Corresponding author) 
total scores of perceived support and missed nursing care $(\mathrm{r}=-0.19 ; \mathrm{P}<0.05)$. Furthermore, significant, inverse correlations were denoted between perceived support and the subscales of missing nursing care $(\mathrm{r}=-0.167$; $\mathrm{P}<0.05)$, as well as perceived support and the primary care subscale $(\mathrm{r}=-134 ; \mathrm{P}<0.05)$. However, no significant associations were observed between perceived support, the personal care subscale, and planning $(\mathrm{P}>0.05)$.

Conclusion: According to the results, perceived supervisory support was correlated with the dimensions of assessment and interventions and primary care regarding missed nursing care. Nursing managers are advised to pursue and implement the support of clinical nurses as a major hospital policy to prevent the loss of care and improve patient safety. As the first-line managers of the clinical environment, nurses may further contribute to nursing care by adopting supportive strategies, thereby increasing patient satisfaction and reducing the treatment costs imposed on patients and the healthcare organization. Our findings could lay the groundwork for monitoring the supportive role of nursing managers, as well as designing and developing effective support models for nursing managers and nurses to improve the primary indicators of nursing care quality.

Keywords: Perceived Support, Clinical Nurse, Missed Nursing Care, Nursing Manager, Care

\section{Conflict of Interest: No}

How to Cite: Vatankhah I, Rezaei M, Baljani E. The Correlation of Missed Nursing Care and Perceived Supervisory Support in Nurses. Iran Journal of Nursing. 2020; 33(126):103-16.

Received: 20 Jul 2020

Accepted: 19 Oct 2020 


\title{
ارتباط مر اقبتهاى برستارى از دست رفته و حمايت سرير ستى درك شده بر ستاران
}

\author{
ايلناز وطن خواه '، منيره رضايیى'، اسفنديار بالجانى؟
}

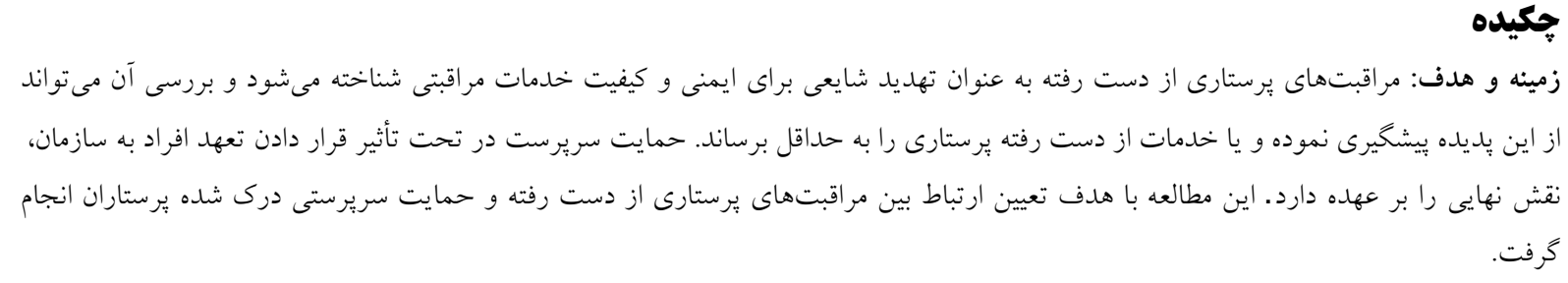

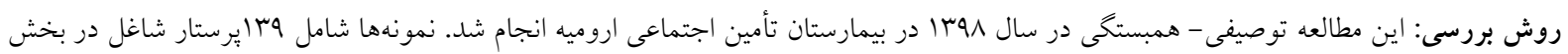

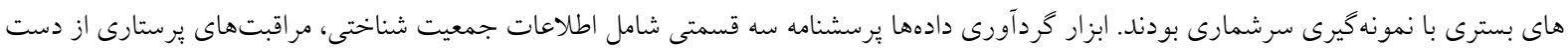

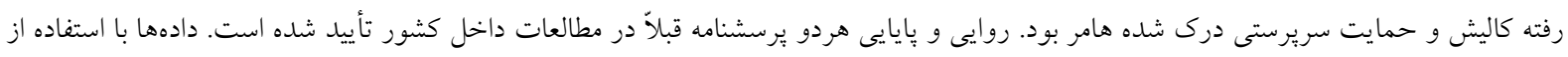

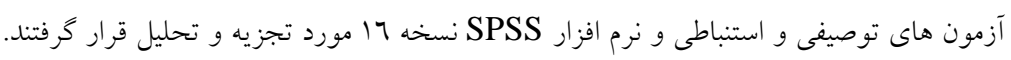

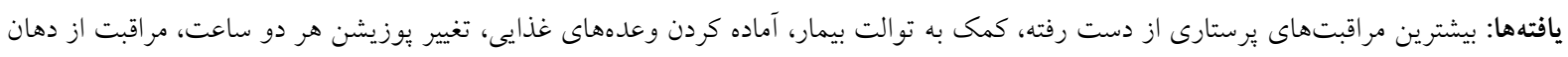

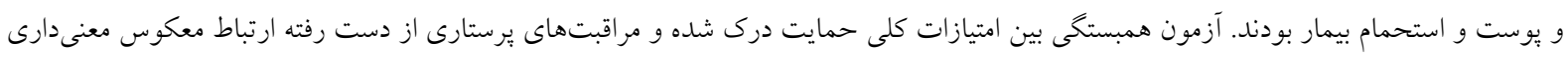

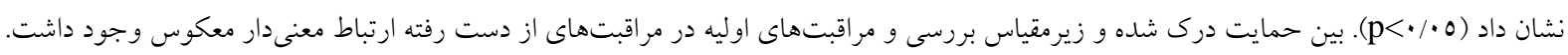

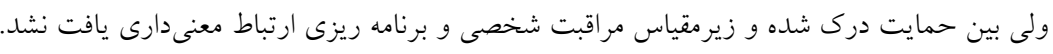

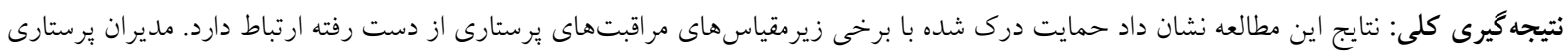

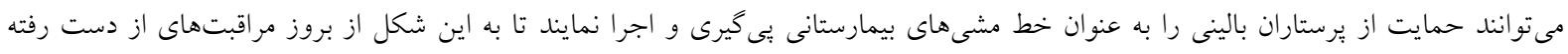
جلو كيرى و ايمنى بيماران را ارتقاء دهند.

كليد وازهها: حمايت، برستار بالينى، مراقبت برستارى از دست رفته، مدير يرستارى، مراقبت

تعارض منافع: ندارد

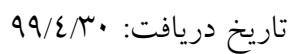
تاريخ بذيرش: 99/N/YN

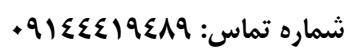

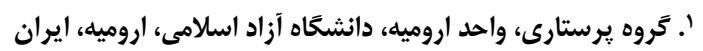

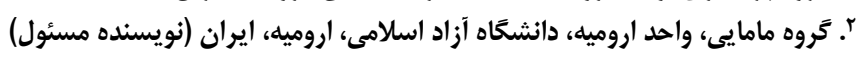

Email: m.rezaei@iaurmia.ac.ir ".ّ تروه برستارى، واحد اروميه، دانشحاه آزاد اسلامى، اروميه، ايران 
از بروز مراقبتهاى از دست رفته جلوكيرى نمايد.

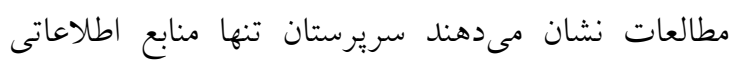
نيستند، اما ادراى كاركنان از موقعيت كارى در سازمان ران تحت تأثير قرار مىدهند، زمانى كه سريرستان از كاركنان حمايت مى كنند، اثر مثبتى بر نتايج رفتار و نكرش كار كاركنان به وجود مى آيد (1.).

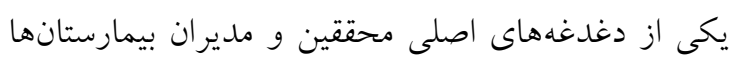

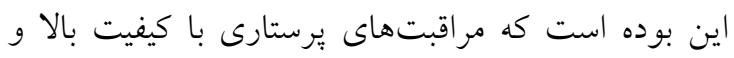

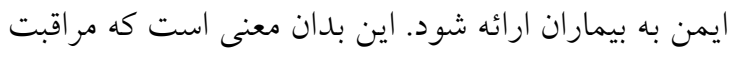

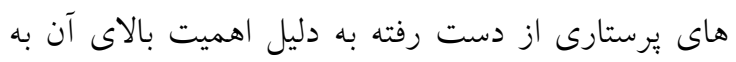

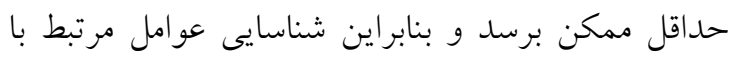

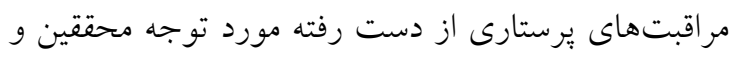

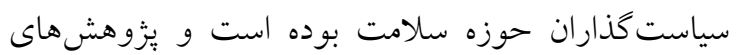
فراوانى در كشورهاى مختلف در خصوص اين امر در حال

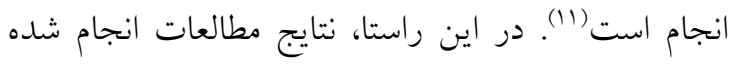
نشان مى دهد كه مراقبتهاى يرستارى از دست رفته رئه

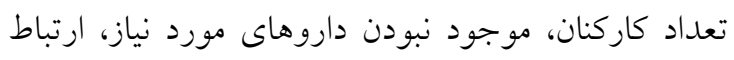

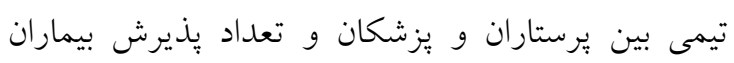
ارتباط معنى دارى دارد (rا, rا'). مراقبتهاى ازدست رفته يرستارى يكى از شاخص دارئ داردي

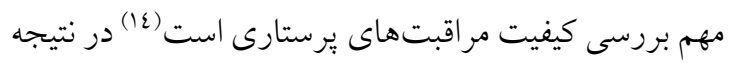

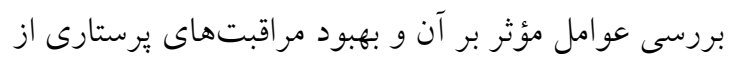

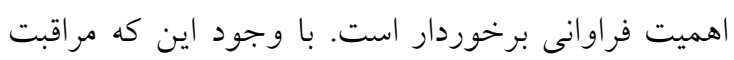

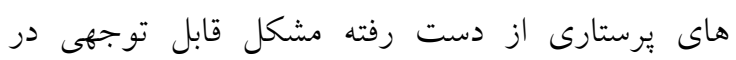

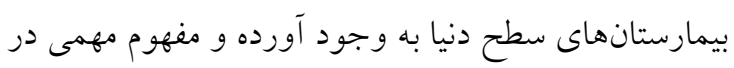

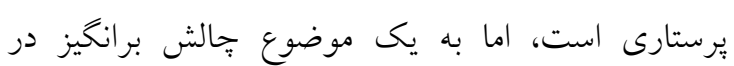

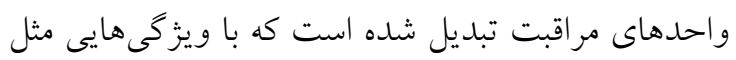

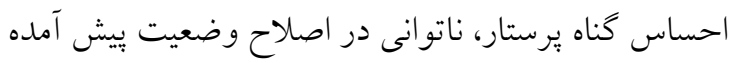

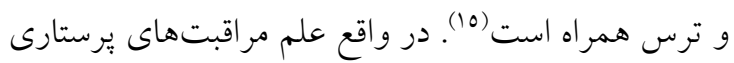

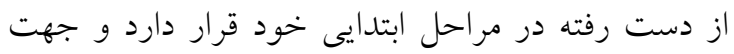
افزايش آكاهى در اين مورد نياز به مطالعات بيشترى

محيط كار برستاران به خاطر ويزگ گهاى خاصى مانند كار

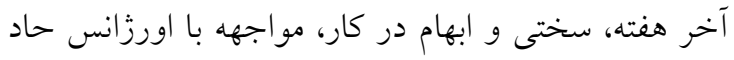

\section{مقدمه}

يكى از اشكال متمايز نقص در مراقبتهاى بهداشتى، مر اقبت هاى برستارى از دست رفته است كه در سطح جهان

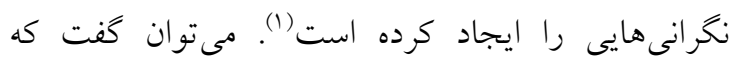

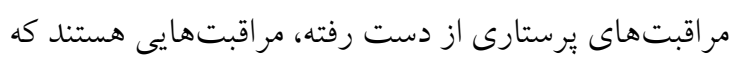

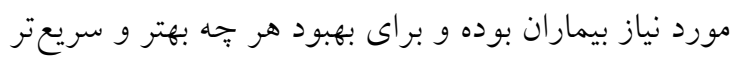

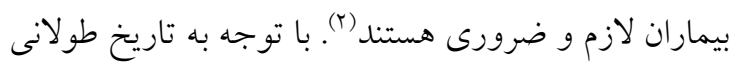
مراقبتهاى برستارى از دست رفته و افزايش بروز آنها و

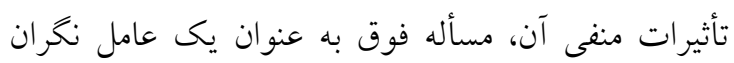
كننده در امر مراقبت مورد توجه قرار كرفته است (r).

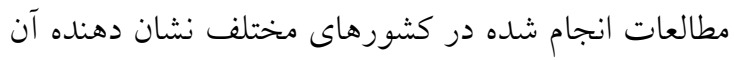

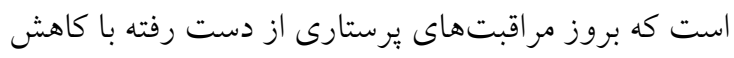
رضايتمندى بيماران، بسترى مجدد بيماران در بيمارستانها، بروز خطاهاى دارويى و عوارض ناشى از مصرف داروها،

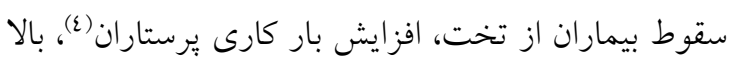

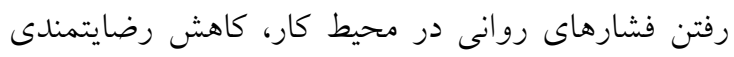

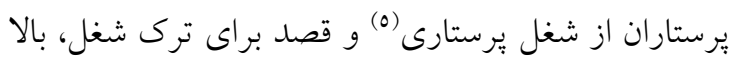
رفتن هزينههاى تحميل شده به بيمار و سازمان مرتبط يطاري است (v) (v) (1)

حمايت سريرست به درجئ حمايت و توجه دريافتى كاركنان از طرف سريرستان خود اشاره دارد. سريرستان جزو اولين سطوح هر سازمان در برخورد با كاركنان سطح

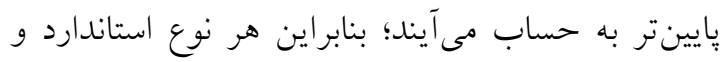

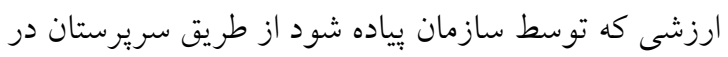

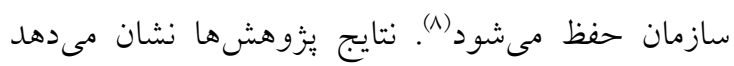

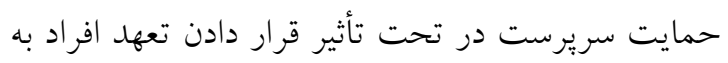
سازمان، نقش نهايى را بر عهده دارد. رفتارها و فعاليتهاى نهري

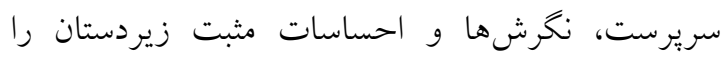
تقويت مى كند و اين موضوع نوعى حس تعهد اخلاقى را در زيردستان ايجاد مى كند. از طرفى حمايت سريرست،

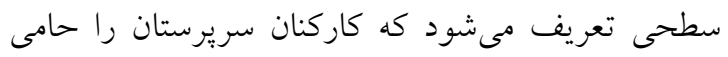

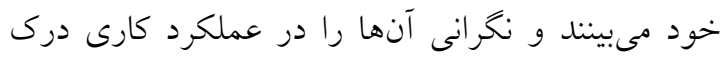

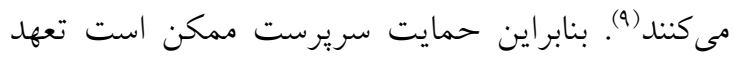
عاطفى و اخلاقى در يرستاران بالينى ايجاد كرده و در نتيجه 
مى تواند از طريق حمايت از برستاران، شرايط كار آنها را

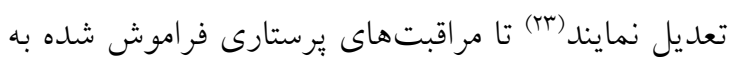

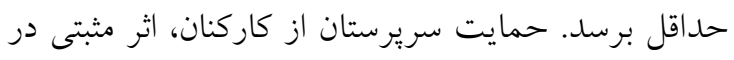
رفتار و نخرش كاركنان خواهد داشت، و ارتباط دوسويه

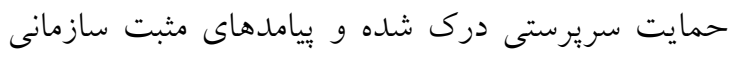
نظير ابقاى كارمند در شغل و بهبود عملكرد كارى، به اثبات

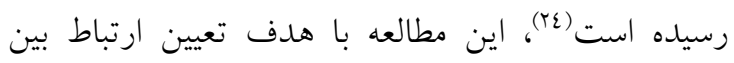
مر اقبتهاى يرستارى از دست رفته و حمايت درى شده

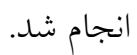

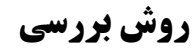

اين مطالعه از نوع توصيفى - همبستخى بوده كه در فاصله

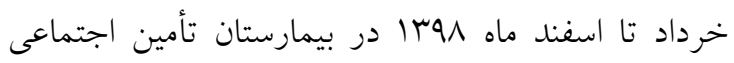

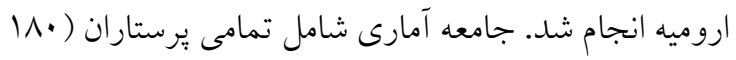

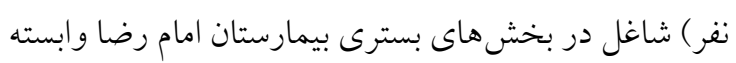

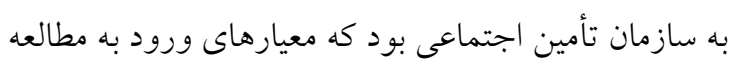

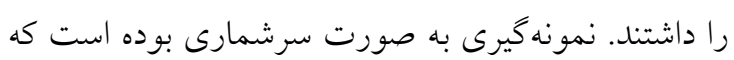

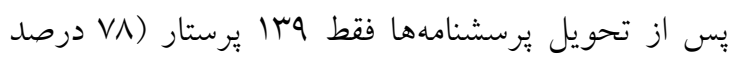

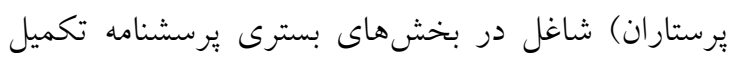

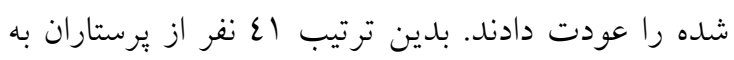

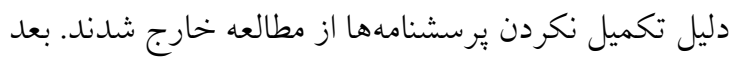

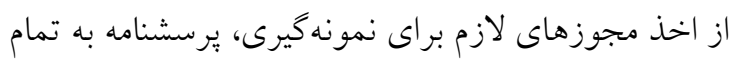
يرستاران در شيفتها و روزهاى مختلف كارى داده شد و

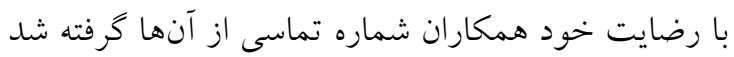
و در همان نوبت كارى يا نوبت كارى بعدى بعد از

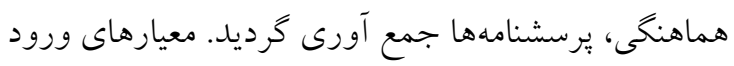

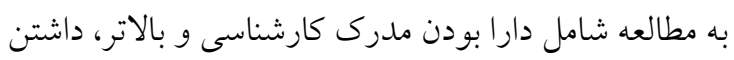

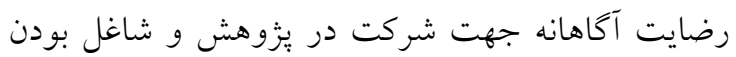

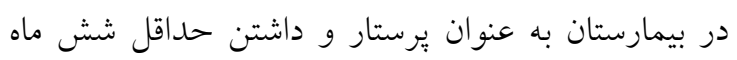
سابقه كار بودند ابزار كردآورى دادهها يك ير سشنامه سه قسمتى بوده است. در قسمت اطلاعات جمعيت شناختى، نام بخش، مدرى فرد تحصيلى، جنسيت، سن، عنوان شغلى، ساعات كارى در

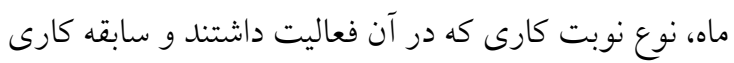

تهايدكننده حيات داراى شرايط خاصى است(V).). اين

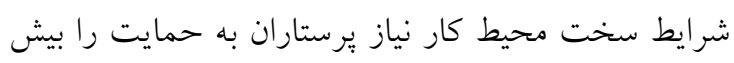

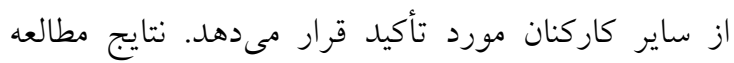

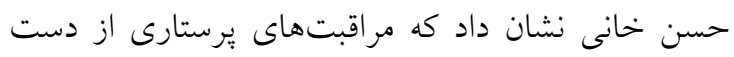
رفته تحت تأثير عوامل محيط كار برستاران مثل حجم كار بالا قرار دارد. اين در حالى است كه سريرستان و مدير ماني

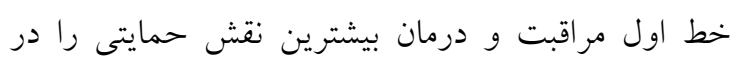

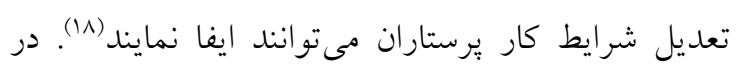

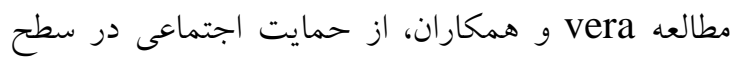
كارهاى گروهى (حمايت سريرست و حمايت همكار) و

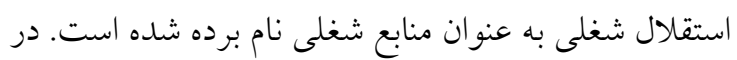

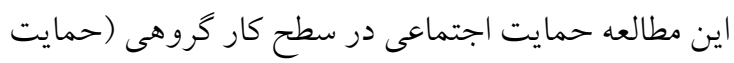

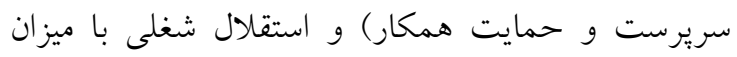

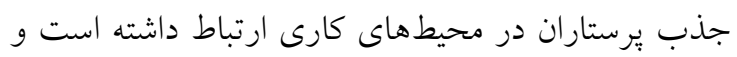

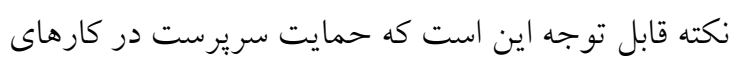
كروهى به عنوان تنها متغير، نقش ميانجى گرى در ارته ارتباط

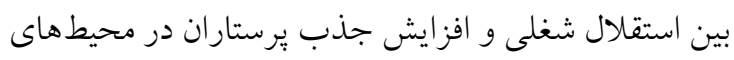
كارى داشته است (19).

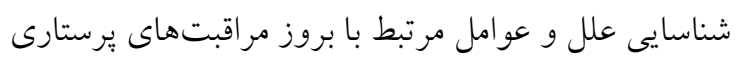

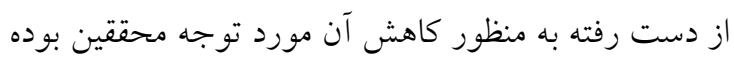

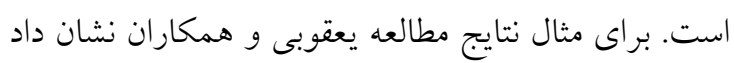

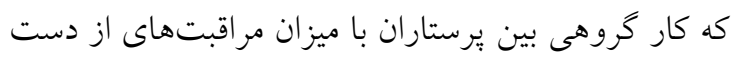

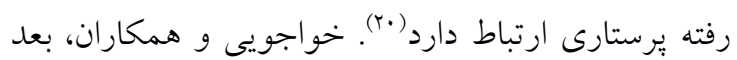

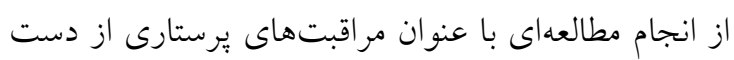

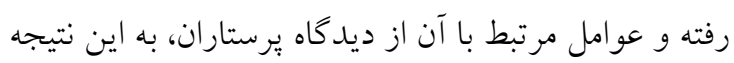
رسيدند كه شرايط محيط كار مثل كمبود نيروى انسانى،

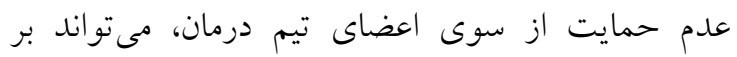
مراقبتهاى يرستارى از دست رفته تأثير داشته باشد. همجنين در مطالعه Hernandez، منابع انسانى و و ارتباطات اعضاى تيم درمانى به عنوان عوامل مؤثر بر

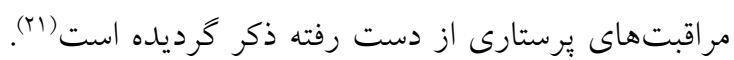

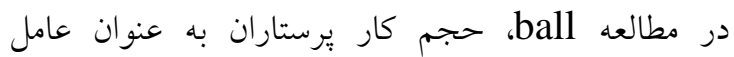
تأثير گذار در بروز مراقبتهاى برستارى از دست رفتمار رفته بيان

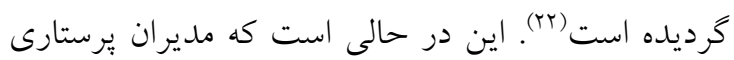


درك شده بيشتر است. زيرمقياسهاى اين برسشنامه شامل

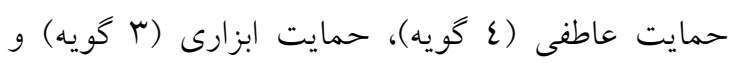

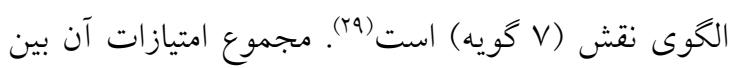

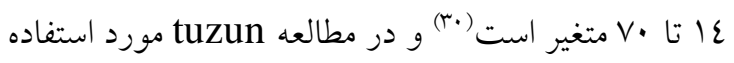

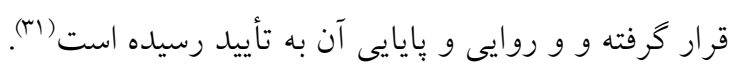

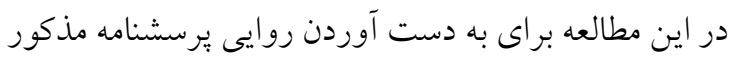

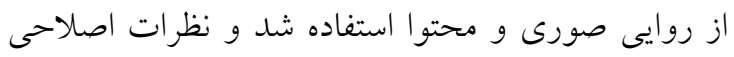

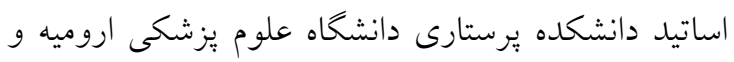

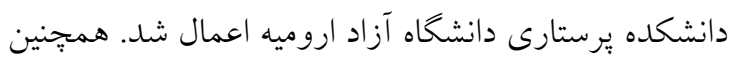

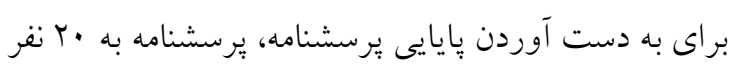

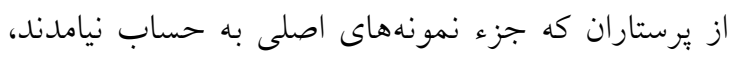

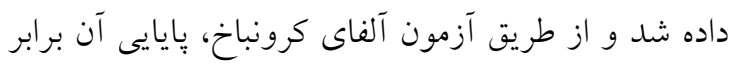
/VA نسخه 17 صورت كرفت. در اين راستا از آمار توصيفى (فراوانى، درصد، ميانخين و انحراف معيار) و آمار

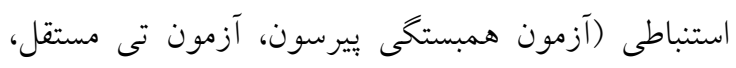

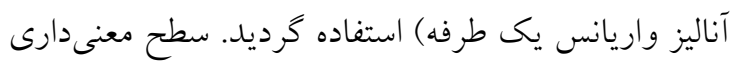
p< مر نظر كرفته شد.

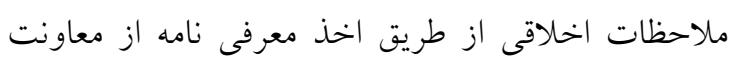

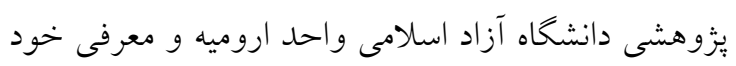

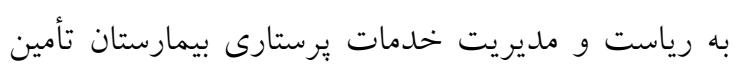

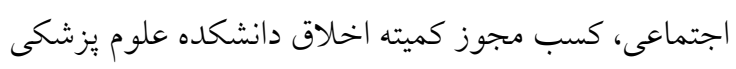
واحد اروميه (IR.IAU.URMIA.REC.1398.013)،

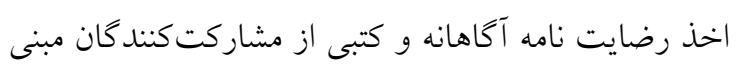
بر اجازه شركت در مطالعه رعايت كرديد.

\section{يافتهها}

جلدول شماره 1 مشخصات جمعيت شناختى يرستاران

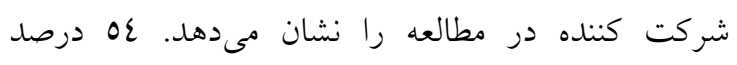

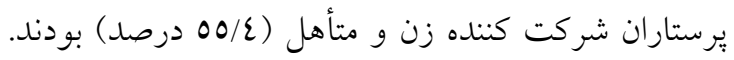

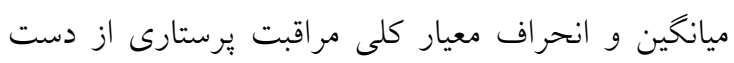

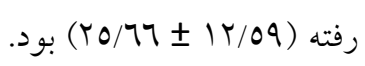

مورد ارزيابى قرار گرفت. بخش دوم شامل يرسشنامه

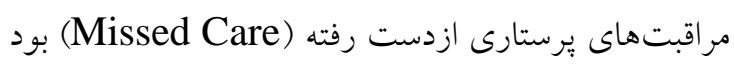

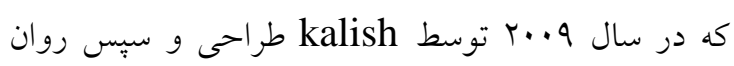

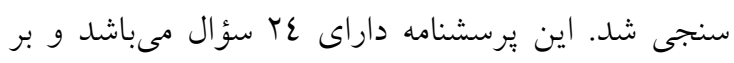
اساس طيف ليكرت با سؤ الاتى مانند (نظارت بر غذا دادن

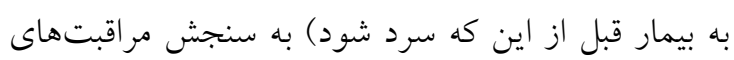

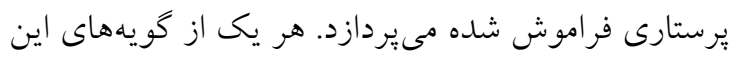

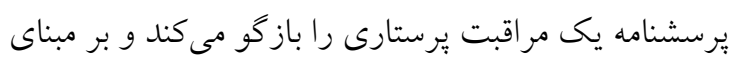

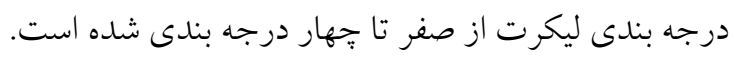

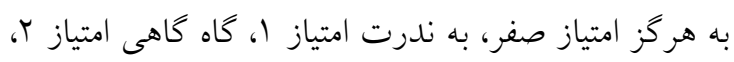

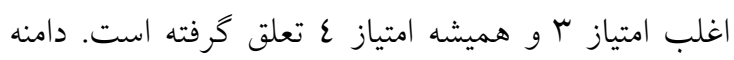

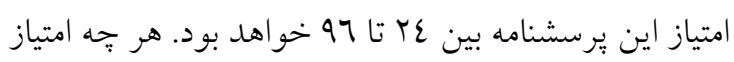
حاصل شده از اين برسشنامه بيشتر باشد، نشان دهنده ميزان

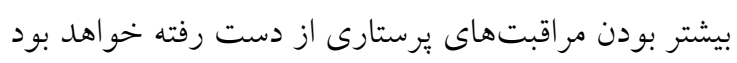

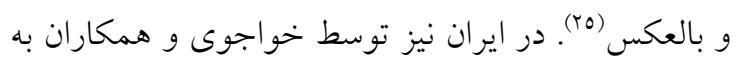

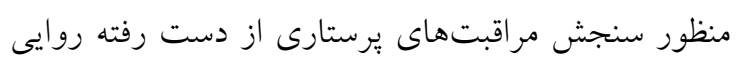

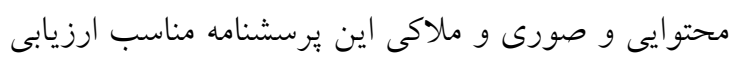

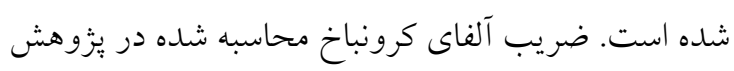

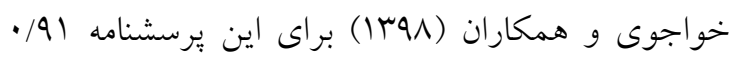

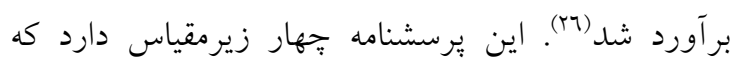
شامل بررسى، مداخلات و مراقبت هاى شخصى، مداخلات

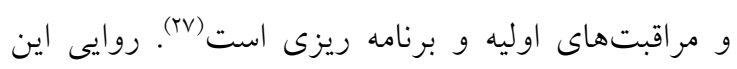

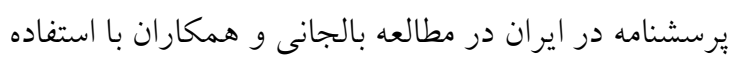

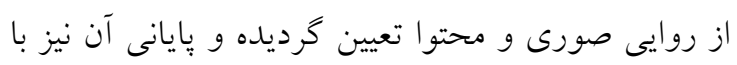

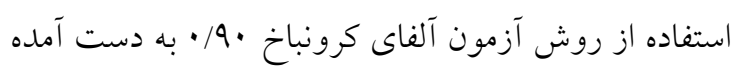

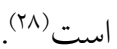
قسمت سوم شامل ابزار استاندارد حمايت درك شده توسط

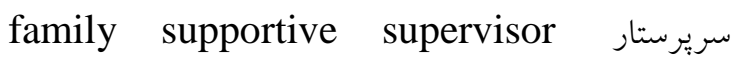
behaviors (FSSB) توسط Hammer در سال 9...r طراحى شده كه اين يرسشنامه بر مبناى درجه بندى ليكرت از يك تا ينج درجه

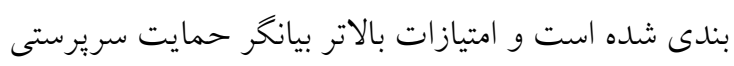




\begin{tabular}{|c|c|c|c|c|c|c|}
\hline \multicolumn{2}{|c|}{ حمايت سريرستى درك شده } & \multicolumn{2}{|c|}{ مراقبت بِرستارى از دست رفته } & \multirow[b]{2}{*}{ تعداد (درصد) } & \multirow[b]{2}{*}{ اجزاى متغير } & \multirow[b]{2}{*}{ 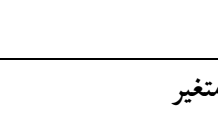 } \\
\hline شاخص هاى & (انحراف & شاخصهاى & (انحر اف معيار) & & & \\
\hline \multirow[t]{24}{*}{ آمارى } & معيار ) ميانكين & آمارى & ميانكين & & & \\
\hline & & $t=r / \varepsilon \varepsilon 1$ & $r q / 0 \cdot \pm(1 T / q \varepsilon)$ & ( & مرد & جنسيت \\
\hline & & $\mathrm{p}=\cdot / \cdot \cdot \mathrm{l}$ & $r r / \varepsilon \cdot \pm(11 / r V)$ & $(0 \varepsilon) V 7$ & زن & \\
\hline & & $t=1 / 07$ & $r V / O 1 \pm(\mid r / \cdot V)$ & r & مجرد & وضعيت تأهل \\
\hline & & $\mathrm{p}=\cdot / T /$ & $r \varepsilon / 1 \Lambda \pm(\mid r / \cdot T)$ & $(00 / \varepsilon) V V$ & متأهل & \\
\hline & & & $\mathrm{p}=\bullet / \cdot r \quad \mathrm{r}=-\cdot / r \tau$ & $(T / \Omega \Lambda) r Y / O \Lambda$ & ميانكين (انحراف & س من، سال \\
\hline & & & & & معيار) & \\
\hline & & $\mathrm{F}=\cdot / \mathrm{NO}_{0}$ & $r \varepsilon / \Gamma V \pm(N / 19)$ & $(1 / \varepsilon) r$ & سريرستار & عنوان شغلى \\
\hline & & $\mathrm{p}=\cdot / \varepsilon \mathrm{V}$ & $\Gamma \mu / \mu I \pm(9 / \backslash \Lambda)$ & $(0 / \Lambda) \wedge$ & استف بخش & \\
\hline & & & $r r / \varepsilon\rceil \pm(\tau / 7 \varepsilon)$ & $(q Y / A) \mid r q$ & يرستار كار در بخش & \\
\hline & & & $\mathrm{p}=\bullet / \wedge 7 \cdot \quad \mathrm{r}=\bullet / / \wedge q$ & $(\Sigma Y / / T) Y / Y / O V$ & ميانكين (انحراف & ساعت كارى در ماه \\
\hline & & & & & معيار) & \\
\hline & & $\mathrm{F}=1 / \pi r$ & $r 0 / r \mu \pm(11 / . r)$ & $(Y / / 7) r$. & صبح & 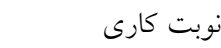 \\
\hline & & $\mathrm{p}=\cdot / \pi \mathrm{q}$ & rN/AT $\pm(1 \cdot / N 1)$ & $(Y / / T) r$. & عصر | | ل مصر & \\
\hline & & & $r \varepsilon / 7 T^{\top} \pm(1 \Gamma / 79)$ & $(07 / \Lambda) \vee q$ & در گردش & \\
\hline & & & $=. / . \cdot \quad \mathrm{r}=-\cdot / T V \varepsilon$ & $(T / r \wedge) Q / T r$ & ميانكين (انحراف & سابقه كارى، سال \\
\hline & & & & & معيار) & \\
\hline & & $p=\cdot / 14$ & $r \cdot / 71 \pm(0 / \mathrm{VI})$ & (ह1) or & بخشهاى عمومى & \\
\hline & & $\mathrm{F}=\cdot / \mu_{0}$ & $T \cdot N T \pm(T / O Y)$ & $(r \cdot / 1) r \Lambda$ & 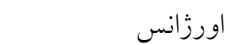 & بخش محل خدمت \\
\hline & & & $19 / 29 \pm(\Sigma / N 1)$ & $(r \varepsilon / 0) r \varepsilon$ & مراقبتهاى ويزه & \\
\hline & & & $r \cdot / 11 \pm(0 / \varepsilon r)$ & $(\mid \varepsilon / \varepsilon) Y$. & كودكان و نوزادان و & \\
\hline & & & & & 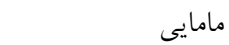 & \\
\hline & & $\mathrm{t}=\cdot / \varepsilon \mu \mathrm{T}$ & $r 0 / 0 . \pm(1 T / 00)$ & $(\Lambda q / r) \mid r \varepsilon$ & كارشناسى & سطح تحصيلات \\
\hline & & $\mathrm{p}=\cdot / 777$ & $|r / r| \pm(|r / Y|)$ & $(1 \cdot / 1) 10$ & كارشناسى ارشد & \\
\hline
\end{tabular}

همجنين نتايج مطالعه نشان داد كه بالاترين ميانگين امتيازات حمايت سريرستى درك شده توسط يرستاران به ترتيب مربوط به كويههاى "اختصاص زمان براى شنيدن

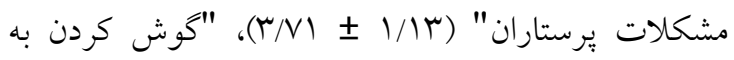

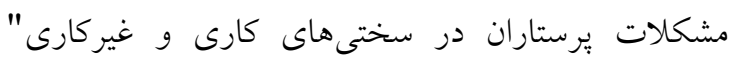

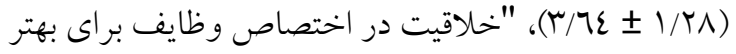

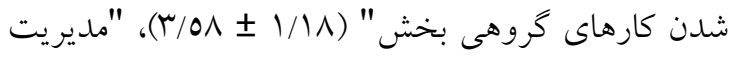

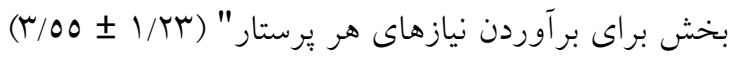
و "استقبال از ييشنهادات براى تسهيل در تعادل نيازهاى براى براي كارى و غيركارى يرستاران" (r//

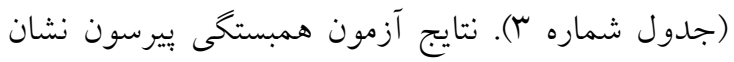

ميانخين و انحراف معيار بالاترين مراقبت برستارى از دست رفته به ترتيب عبارت از كمك كردن به توالت بيمار در

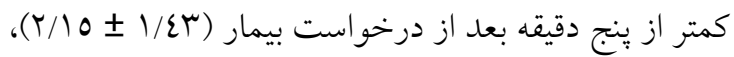

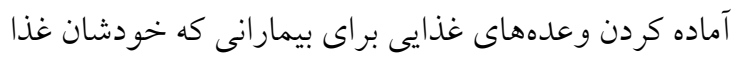

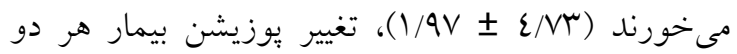
ساعت (1/N

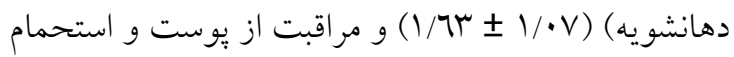

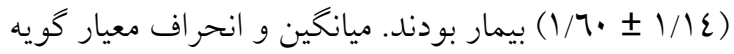
هاى مراقبتهاى يرستارى از دست رفته در جدول شماره

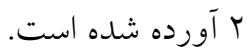




$$
\begin{aligned}
& \text { داد كه بين حمايت سريرستى درك شده و مراقبتهاى افزايش حمايت سريرستارى درك شده امتيازات مراقبت }
\end{aligned}
$$

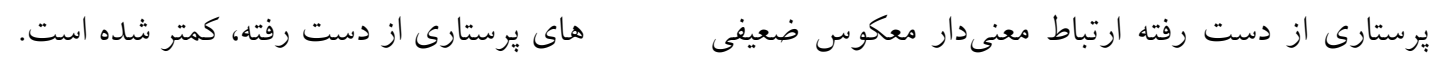

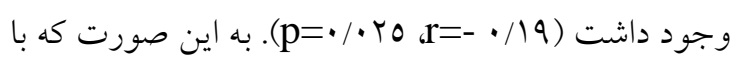

جدول شماره ז: وضعيت مراقبت هاى يرستارى از دست رفته در بيمارستان تامين اجتماعى اروميه از ديدكاه يرستاران

\begin{tabular}{|c|c|c|c|}
\hline انحر اف معيار & 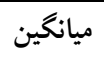 & وظايف برستارى & 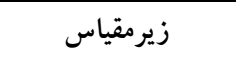 \\
\hline$\cdot / \wedge 0$ & $\cdot / \Lambda$ & 1- بررسى علاثم حياتى طبق دستور & \\
\hline$\cdot / \wedge \varepsilon$ & • & r- كترل جذب و دفع & \\
\hline$\cdot / \wedge \cdot$ & $\cdot 101$ & r- مستندسازى اطلاعات ضرورى & 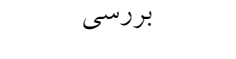 \\
\hline $1 / \cdot r$ & $1 / 19$ & ع- شستشوى دستها & \\
\hline$\cdot / 79$ & $\cdot / \varepsilon \vee$ & 0- كترل قند خون & \\
\hline$\cdot / 9 \pi$ & $\cdot / \mathrm{v}$ & 7- بررسى و شناخت در هر شيفت & \\
\hline $1 / \cdot r$ & $1 / 11$ & V- V ارزيابى بيمار بر حسب شرايط & \\
\hline$\cdot / 77$ & $\cdot / 0 r$ & 1- كترل كترهاى وريدى & \\
\hline$r / \Lambda Y$ & $0 / \Gamma \Lambda$ & 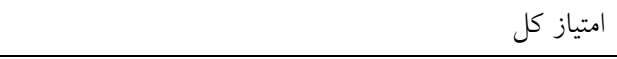 & \\
\hline$\cdot / 94$ & $\cdot / N T$ & 1- دارودهى در •r دقيقه قبل يا بعد برنامه روزانه دارو & \\
\hline $1 / \cdot 9$ & $1 / r 7$ & r- جمايت عاطفى و روحى بيمار & \\
\hline$\cdot / 91$ & $\cdot / \sqrt{ } 9$ & זَ-باسخ به زنخ اخبار در كمتر از 0 دقيقه & مداخلات و مراقبت \\
\hline$\cdot / \wedge \cdot$ & $\cdot / 7 \Lambda$ & ع- اجراى دستوراتPRN در كمتر از 10 دقيقه & هاى شخصى \\
\hline $1 / 1$. & $1 / 1 \varepsilon$ & 0- بررسى تأثير و كارايى درمانى داروها & \\
\hline $1 / \varepsilon r$ & $r / 10$ & 7- كمك به توالت بيمار در كمتر از0 دقيقه از درخواست & \\
\hline$r / M$ & $7 / V \varepsilon$ & امتياز كل & \\
\hline $1 / \cdot 0$ & $1 / \varepsilon r$ & 1- حركت بيمار بَ بار در روز يا طبق دستور & \\
\hline $1 / 11$ & $1 / 7 \pi$ & r- r تغيير يوزيشن هر r ساعت & \\
\hline 1/10 & $1 / \pi \wedge$ & r- ب- تغذيه بيمار زمانى كه غذا كرم است & \\
\hline$\varepsilon / N r$ & 1/9V & ع- آماده كردن وعده غذايى براى بيماران & مداخلات و مراقبت \\
\hline $1 / 1 \varepsilon$ & 1/7. & 0- م- مراقبت از يوست و استحمام & 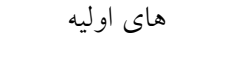 \\
\hline $1 / \cdot v$ & $1 / 7 \pi$ & 7- اقبت از دهان & \\
\hline$\cdot / 9 \mathrm{~V}$ & $\cdot / 94$ & V- V- Vمراقبت از زخم & \\
\hline T/OV & $1 \cdot / 7 r$ & 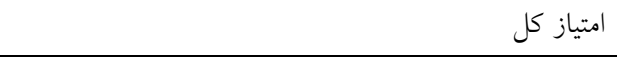 & \\
\hline$\cdot / 9 \varepsilon$ & $\cdot / 90$ & 1- آموزش به بيمار درمورد بيمارى، آزمايشات و.. & برنامه ريزى \\
\hline.$/ 91$ & $\cdot /$ No & r- ب-رخيص بيمار و آموزش وى & \\
\hline $1 / 70$ & $1 / \pi r$ & r-- حضور در كلاسهاى آموزشى و كنغرانسها & \\
\hline$T / Y$. & $r / \cdot 1$ & امتياز كل & \\
\hline $1 T / 09$ & ro/77 & \multicolumn{2}{|c|}{ متياز كلى مراقبت برستارى از دست رفته } \\
\hline
\end{tabular}




\begin{tabular}{|c|c|c|}
\hline 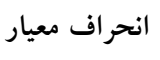 & 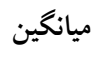 & زيزمقياس هاى حمايت درك شده \\
\hline $1 / \Gamma \wedge$ & $\mu / \nearrow \varepsilon$ & سريرست من مايل است كه در سختىهاى كارى و غير كارى به مشكلات من گوش كند. \\
\hline $1 / 14$ & r/NI & سريرست من زمان براى شنيدن مشكلات من اختصاص مىدهد. \\
\hline $1 / T r$ & $r / \varepsilon V$ & سريرست من باعث مىشود من براى صحبت كردن در مورد تضادهاى كارى و غير كارى احساس راحتى كنم. \\
\hline$|/ r|$ & $r / 2 V$ & من و سريرستم مىتوانيم به طور مؤثر براى حل تضادهاى كارى و مسائل غير كارى با هم صحبت كنيم. \\
\hline $1 / 1 \cdot$ & $r / \varepsilon$. & من مىتوانم به سريرست خود متكى باشم تا در صورت نياز به آن با زمان بندى تضادها به من كمك كند \\
\hline $1 / 19$ & $r / \varepsilon$. & من مىتوانم به كمك سريرست خود در زمان نيازهاى غيرمنتظره خارج از مسئوليتهاى كارى تكيه كنم. \\
\hline $1 / r V$ & $r / \varepsilon r$ & سريرست من به طور مؤثر براى حل خلاقانه تضادهاى بين كار و محيط بيرون تلاش مى كند. \\
\hline $1 / 19$ & $r / \mathrm{rV}$ & سريرست من يكى الخوى نقش براى تعادل امور مربوط به كار و غير كار است. \\
\hline $1 / 1 \varepsilon$ & $r / \Sigma 0$ & سريرست من رفتارهاى مؤثر براى جخونكى حل و فصل تعادل كار و امور غير كار نشان مىدهد \\
\hline \multirow[t]{2}{*}{$1 / 1 \mathrm{~V}$} & $r / \varepsilon r$ & سريرست من نشان مىدهد جِكونه يك فرد مىتواند همزمان در وظايف كارى و بيرون از كار موفق باشد. مديريت \\
\hline & & موفق كار - خانو اده \\
\hline \multirow[t]{2}{*}{$1 / 10$} & $r / \varepsilon V$ & سريرست من عقيده دارد كه مىتوان كار در بخش را طورى سازماندهى كرد كه كاركنان و شركت را به طور مشترى \\
\hline & & 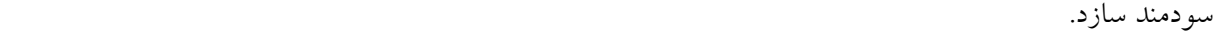 \\
\hline $1 / 1 r$ & r/Or & سريرست من از ييشنهادات براى تسهيل در تعادل نيازهاى كار - غير كارى كاركنان استقبال مىكند \\
\hline \multirow[t]{2}{*}{$1 / 1 \wedge$} & $r / 01$ & سريرست من خلاقيت لازم در اختصاص وظايف را دارد تا به بهتر شدن كارهاى گروهى بخش محل كار من كمك \\
\hline & & \\
\hline $1 / \pi \mu$ & $r / 00$ & سريرست من قادر به مديريت بخش به عنوان يك تيم كل براى برآورده كردن نيازهاى هر فرد است. \\
\hline $\mid r / \mathrm{N}$ & $\varepsilon \Lambda / v$ & 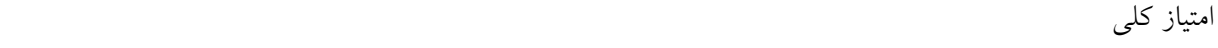 \\
\hline
\end{tabular}

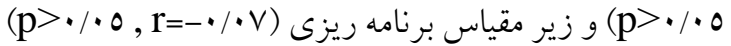
ارتباط معنى دارى يافت نشد (جدول شماره ع). امتياز كلى و ميانخينهاى هر كدام از زيرمقياسهاى حمايت سريرستى درى شده در بِرستاران شاغل در بيمارستان تأمين اجتماعى اروميه در جدول شماره O به تفكيك آورده شده است.
همجنين بين امتيازات حمايت درك شده و زير مقياس مداخلات و مراقبتهاى اوليه مراقبتهاى يرستارى از دست رفته ارتباط معنى دار معكوس ضعيف وجود داشت (p=•/• ع , r=-•/lV)

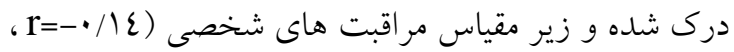

جدول شماره F: همبستكى بين زير مقياس حمايت درك شده با زير مقياس مراقبتهاى يرستارى از دست رفته در يرستاران شاغل در بيمارستان تأمين اجتماعى اروميه

\begin{tabular}{|c|c|c|c|c|c|}
\hline مر اقبت هاى برستارى & برنامه ريزى & مراقبتهاى اوليه & مراقبت هاى & ارزيابى & حمايت سربرستى درى شده بره \\
\hline $\mathrm{p}=\cdot / \cdot 1 \mathrm{~V}$ & $\mathrm{p}=\cdot / \mu \cdot q$ & $\mathrm{p}=\cdot / \cdot\{1$ & $\mathrm{p}=\cdot / \cdot v r$ & $\mathrm{p}=\cdot / \cdot 71$ & بعد عاطفى \\
\hline $\mathrm{rr}=-\cdot / \mathrm{r} \cdot 1$ & $\mathrm{r}=-\cdot / \cdot \wedge \mathrm{V}$ & $\mathrm{r}=-\cdot / l \vee \varepsilon$ & $r=-\cdot / 10 r$ & $r=-\cdot / 109$ & \\
\hline $\mathrm{p}=\cdot / \cdot r$ & $\mathrm{p}=\cdot / 20 \wedge$ & $\mathrm{p}=\cdot / 1 \cdot$ & $\mathrm{p}=\cdot / \cdot$ or & $\mathrm{p}=\cdot / .07$ & بعد ابزارى \\
\hline $\mathrm{r}=-\cdot / \backslash \wedge \varepsilon$ & $r=-\cdot / \cdot 7 r$ & $\mathrm{r}=-\bullet / / \varepsilon$. & $r=-\cdot / 17 \varepsilon$ & $r_{-} \cdot / 17 r$ & \\
\hline$p=\cdot / \cdot r V$ & $\mathrm{p}=\cdot / \varepsilon \wedge \varepsilon$ & $\mathrm{p}=\cdot / \cdot 71$ & $\mathrm{p}=\cdot / T / \wedge$ & $\mathrm{p}=\cdot / \cdot$ or & بعد ايفاى نقش \\
\hline $\mathrm{r}=-\cdot / / \mathrm{V} \wedge$ & $\mathrm{r}=-\bullet / \cdot\urcorner$ & $\mathrm{r}=-\bullet / 17$ & $r=-\cdot / 1 \cdot 7$ & $\mathrm{r}-\cdot / 170$ & \\
\hline $\mathrm{p}=\cdot / \cdot \mathrm{ro}_{\mathrm{O}}$ & $\mathrm{p}=\cdot / \varepsilon r q$ & $\mathrm{p}=\cdot / \cdot \Delta \varepsilon$ & $\mathrm{p}=\cdot / 11 \wedge$ & $\mathrm{p}=\cdot / \cdot 0$ & حمايت سريرستى درك شده \\
\hline$r=-\cdot / 19$. & $\mathrm{r}=-\cdot / \cdot 77$ & $r=-\cdot / / 7 \varepsilon$ & $r=-\cdot / 1 r \varepsilon$ & $r_{-} \cdot / 17 V$ & \\
\hline
\end{tabular}


جدول شماره ه: زير مقياس هاى حمايت سريرستى درك شده در يرستاران شاغل در بيمارستان تأمين اجتماعى اروميه

\begin{tabular}{|c|c|c|c|c|c|}
\hline دامنه & 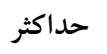 & 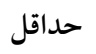 & انحر اف معيار & 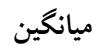 & ابعاد حمايت سريرستى درك شده \\
\hline 17 & r. & $\varepsilon$ & $\varepsilon / \varepsilon r$ & $\mid \varepsilon / T \wedge$ & بعد عاطفى (·r-乏) \\
\hline ir & 10 & r & r/r八 & $1 \cdot / r r$ & بعد ابزارى (10-1) \\
\hline r^ & ro & $\checkmark$ & 7/9 & $r \varepsilon / T \wedge$ & بعد ايفاى نقش (V-YO) \\
\hline 07 & v. & $1 \varepsilon$ & $|r / v|$ & $\varepsilon \wedge / \vee T$ & امتيازات كلى حمايت سريرستى درك شده (•V-ع |) \\
\hline
\end{tabular}

ضعيف وجود دارد. اين نتيجه بدين معنى است كه با افزايش ميزان حمايت سريرستى درى شده، ميزان مراقبت هاى برستارى از دست رفته كمتر مىشود. در صورتى كه بين حوزه مداخلات و مراقبتهاى شخصى و زيرمقياس برنامه ريزى مراقبتهاى برستارى از دست رفته با مراقبت هاى يرستارى از دست رفته ارتباط معنى دار وجود نداشت. هرجند هيج مطالعهاى ارتباط بين حمايت درك شده و مراقبتهاى يرستارى از دست رفته را مورد بررسى قرار نداده است، اما شواهدى وجود دارد كه نشان مىدهد حمايت سريرستى درى شده با بياملهاى مثبت سازمانى

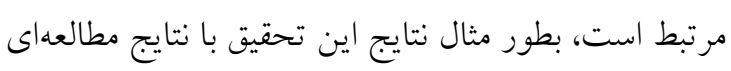
كه در بيمارستانهاى خصوصى كشور تركيه انجام شده بود، قابل مقايسه است. نتايح آن تحقيق بيانخر اين بوده است كه بين حمايت سريرستى درك شده و رضايت شغلى ارتباط وجود داشت (عَ). همجنين نتايج اين تحقيق با نتايج تحقيق tuzan نشان داد كه بين حمايت درى شده و تمايل به ترك شغل در بين كاركنان شركت بيمه ارتباط معكوس وجود داشت(ro). همجينين نتايج اين مطالعه با مطالعه يعقوبى و همكاران قابل مقايسه است، در آن مطالعه نتايج بيانگر اين است كه با افزايش كار گروهى بين يرستاران ميزان مراقبت هاى از دست رفته يرستارى كاهش مى يابد (r). در مطالعه vera سريرست، حمايت همكار و استقلال شغلى با ميزان جذب لئب يرستاران در محيطهاى كارى ارتباط داشته است و نكته قابل توجه اين است كه حمايت سريرست در كارهاى كروهى بـه عنوان تنها متغير، نقش ميانجى گرى در ارتباط

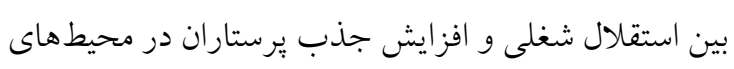

\section{بحث و نتيجه كيرى}

حمايت سريرست به درجهُ حمايت و توجه دريافتى كاركنان از طرف سريرستان خود اشاره دارد و حمايت سريرست ادراك شده زمانى اتفاق مى افتد كه كاركنان درى كنند، سريرستان براى مشاركت آنان ارزش قائل مىشوند و به رفاه، علايق و آسايش ايشان اهميت مىدهند؛ زيرا سريرستان از طرف سازمان انتخاب مىشوند و مسئوليت راهنمايى كردن كاركنان و ارزيابى عملكرد آنان را بر عهده دارند (rr). بنابراين از اين نظر مىتوان نتايج اين مطالعه را با نتايج مطالعه رضايى و همكاران مقايسه كرد. در مطالعه رضايى و همكاران كه به تعيين حمايت اجتماعى برستاران

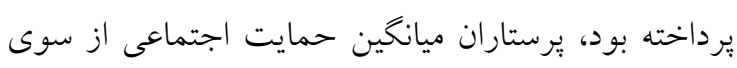

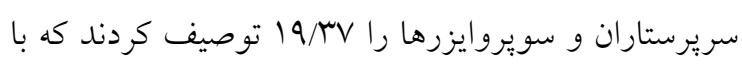
توجه به مقياسبندى يرسشنامه بكاررفته، اين ميزان متوسط تلقى شده بود (rآ). در مطالعه حاضر با توجه به دامنه امتياز يرسشنامه حمايت درك شلده كه بين عا تا •V ل بوده و امتياز بيشتر نشان دهنده ميزان حمايت درك شده بيشتر مىباشد، امتياز كلى حمايت درك شده ( (LN/NT حد متوسط تلقى مىشود. در مطالعه حاضر بالا بودن

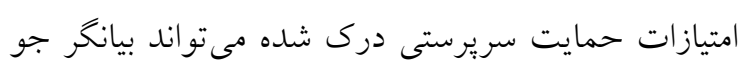
همكارى مثبت بين سريرستاران و سوبرو ايزرها با برستاران شركت كننده در اين مطالعه باشد كه احساس درك همديخر را تقويت كرده است. در مورد ارتباط بين مراقبتهاى يرستارى از دست رفته و حمايت درك شده توسط سريرست، نتايج اين مطالعه نشان داد كه بين زيرمقياس بررسى و زيرمقياس مداخلات و مراقبتهاى اوليه مراقبتهاى برستارى از دست رفته با

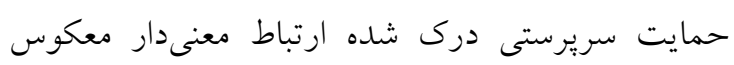


همكاران، بيشترين ميانخين مراقبت برستارى فراموش شده به شركت در كنفرانسهاى بين رشتهاى مراقبت از بيمار

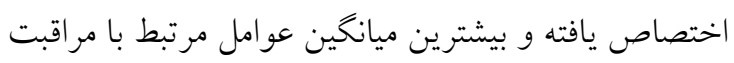

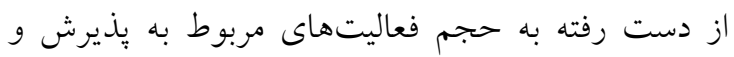

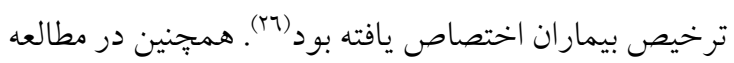

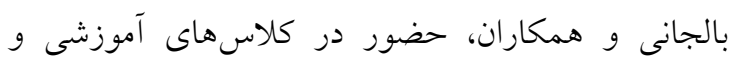
كنفر انسها، مراقبت از زخم، كنترل قند خون در كنار تخت

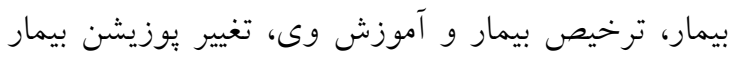
هر دو ساعت، مراقبت از كاتترهاى وريدى يا مركزى و ارزيابى بر اساس دستورها و خط مشىهاى بيمارستانى جزء بيشترين مراقبتهاى يرستارى از دست رفته در

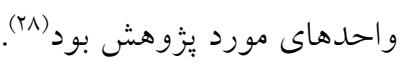

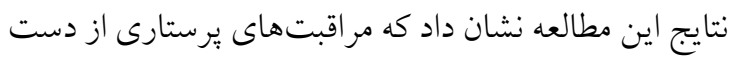
رفته در برستاران مرد نسبت به يرستاران زن بيشتر بود. در تحليل اين نتيجه به نظر مىرسد از آن جائى كه در يرستاران

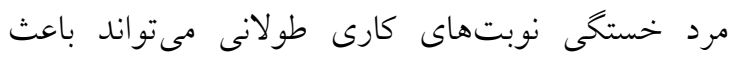
افزايش مراقبتهاى برستارى از دست رفته شود، بنابراين

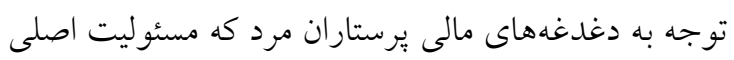

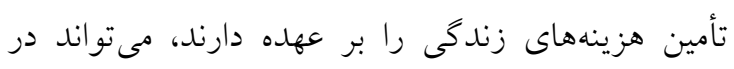

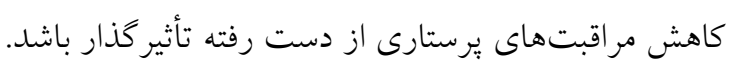

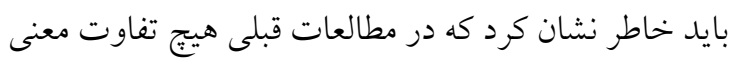

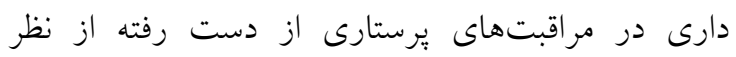

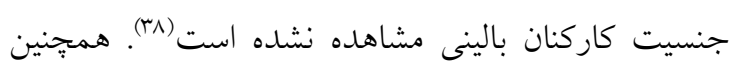

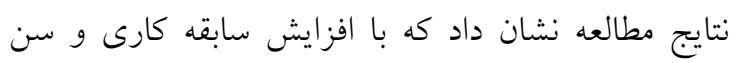

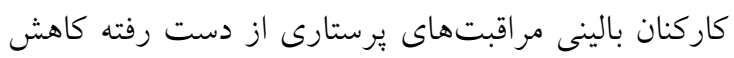

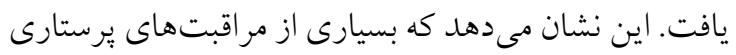
مربوط به عدم كسب تجربه و يا فاصله بين تئورى و بالين است و برستاران بعد از مدتى حضور در بخشهاى بـ بالينى

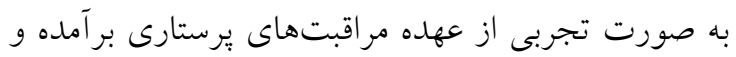

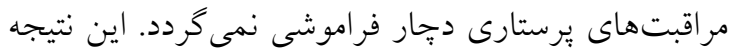

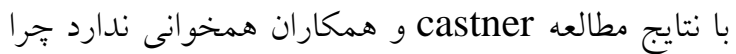
كه نتايج آن مطالعه نشان داد كه سابقه شغلى بيشتر منجر به

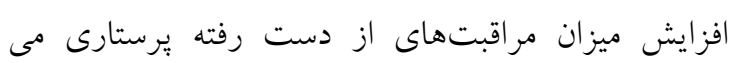

كارى داشته است (19). در تبيين اين نتيجه، به نظر مىرسد حمايت مديران يرستارى از طريق تغيير برخى شر ايط كار

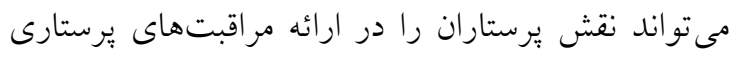

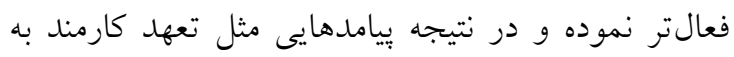

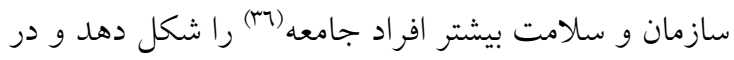
نتيجه، در خنين شرايط كارى احتمال وقوع خطاهاى كارى سي يرستارى و مراقبتهاى يرستارى از دست رفته به حداقل

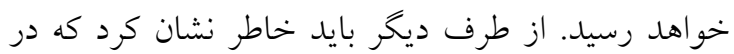
حرفه يُرستارى، حمايت سريرست به عنوان منبع مهم حمايت اجتماعى توصيف شده است، به اين دليل كه آنها

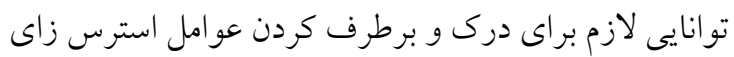
محيط كار، سازگًارى با استرس، ارتقاى سلامت بر برستاران، رشد حرفهاى آنها و توسعه شغلى را دارا هستند (rV).

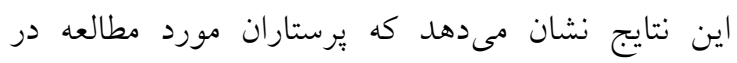

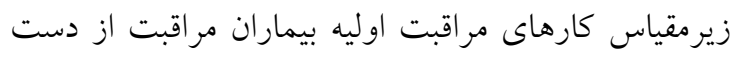
رفته بيشترى دارند. نتايج مطالعه حاضر در اين رابطه با مافيا يافتههاى تحقيق winsett و همكاران قابل مقايسه است. محققين در تفسير نتايج آن مطالعه بيان كردهاند كه بروز

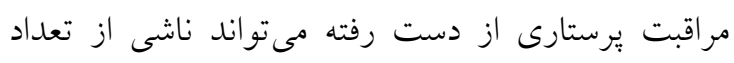

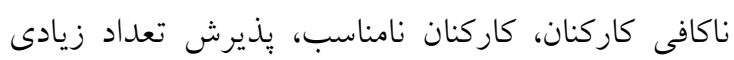
بيمار و دسترسى نداشتن به داروهاى مورد نياز باشد (TV).

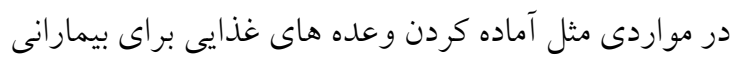

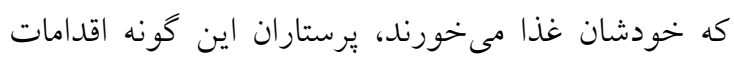

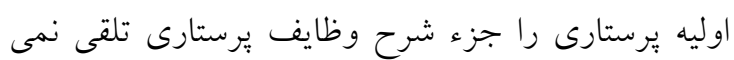

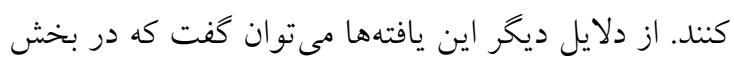

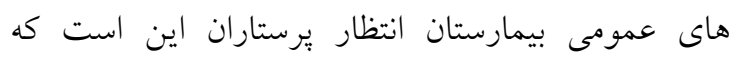

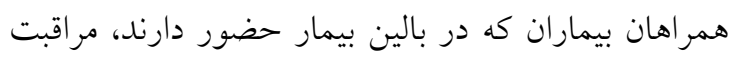

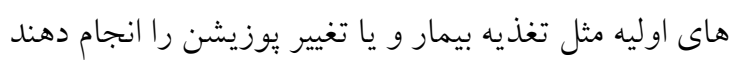

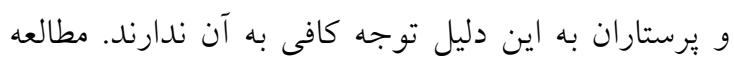

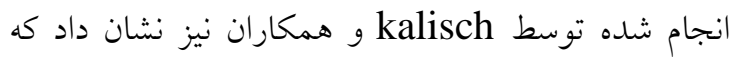

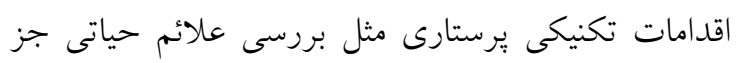

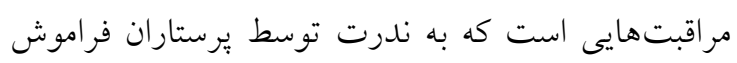

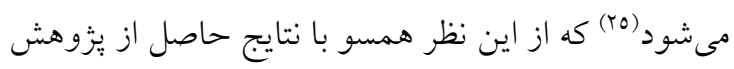

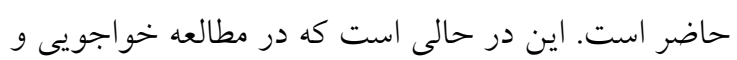


نتايج اين تحقيق نشان داد كه برخى حوزههاى حمايت سريرستى درك شده با مراقبتهاى يرستارى از دست رفته

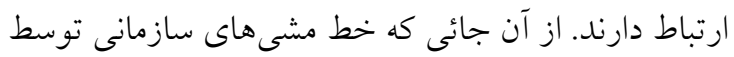

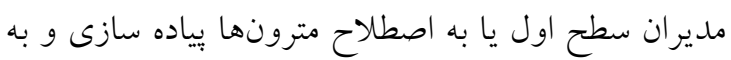

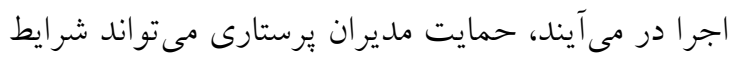

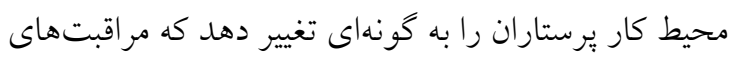
يرستارى از دست رفته به حداقل كاهش يايد. بنابراين

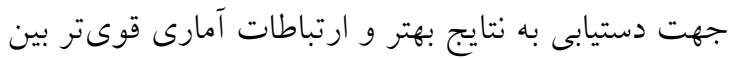
متغيرهاى تحقيق توصيه مىشود، مشابه اين مطالعه در تمام كاركنان بالينى بيمارستانها در شهرهاى مختلف و با نمونه

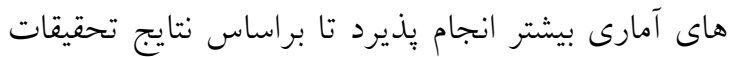
بتوان تصميم گيرىهاى اساسى در راستاى حل مشكلات

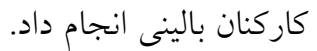

تعارض منافع: نويسندگان هيج كونه تعارضى در منافع را

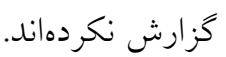

\section{تقدير و تشكر}

اين مطالعه بركرفته از پايان نامه دانشجويى در مقطع كارشناسى ارشد يِرستارى است. نويسند كان كمال تشكر را از معاونت يزّوهشى دانشگاه آزاد اسلامى واحد اروميه ابراز مىدارند. همجنين نويسندكان كمال قدردانى را از برستاران شركت كننده در اين مطالعه ابراز مى كنند.
همجينين نتايج اين مطالعه نشان داد كه از نظر ابعاد تشكيل دهنده، بيشترين حمايت سريرستى مربوط به بعل حمايت عاطفى بود. در متون علمى حمايت عاطفى به معنى درك و

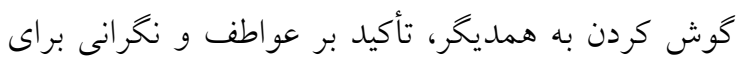

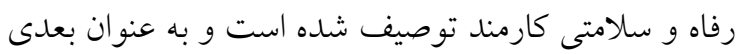

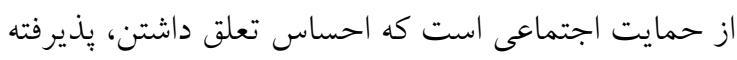

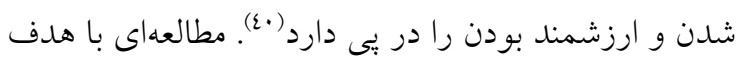
تعيين حمايت سريرستى درك شده توسط سريرستار يافت

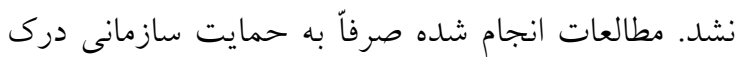
شده و حمايت اجتماعى درك شده از ديدكاه يرستاران يرداخته است، بنابراين از اين نظر قابل مقايسه با مطالعات مشابه نيست. اين مطالعه به صورت مقطعى و با استفاده از يرسشنامه خوداظهارى انجام كرديده است. اين احتمال وجود دارد كه پاسخهاى يرستاران به خاطر حجم كار بالا و ساير شر ايط

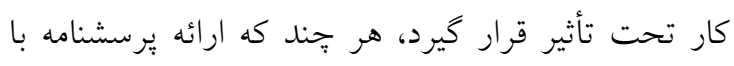
هماهنكى و رضايت كامل مشاركت كنند كان صورت كرفته بود، ولى از اين نظر محدوديت به حساب مئى آيد. بيشنهاد

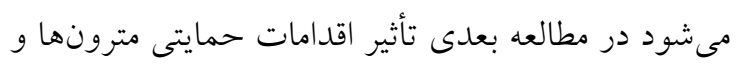

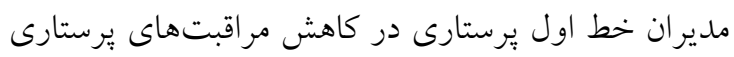

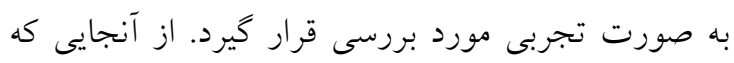
اين ثزوهش در يكى از بيمارستانهاى شهر اروميه انجام

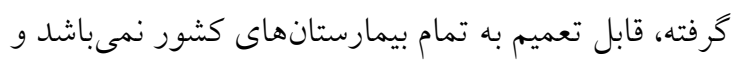

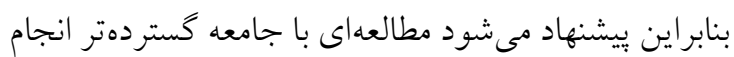
كيرد.

\section{References}

1. Jones TL, Hamilton P, Murry N. Unfinished nursing care, missed care, and implicitly rationed care: State of the science review. Int J Nurs Stud. 2015;52(6):1121-37.

2. Siqueira LD, Caliri MH, Kalisch B, Dantas RA. Cultural adaptation and internal consistency analysis of the MISSCARE Survey for use in Brazil. Revista latino-americana de enfermagem. 2013;21(2):610-7.

3. De Villers MJ, DeVon HA. Moral distress and avoidance behavior in nurses working in critical care and noncritical care units. Nursing ethics. 2013;20(5):589-603.

4. Kowinsky AM, Shovel J, McLaughlin M, Vertacnik L, Greenhouse PK, Martin SC, Minnier TE. Separating predictable and unpredictable work to manage interruptions and promote safe and effective work flow. J Nurs Care Qual. 2012;27(2):109-15. 
5. Bogossian F, Winters-Chang P, Tuckett A. "The Pure Hard Slog That Nursing Is...": A Qualitative Analysis of Nursing Work. J Nurs Scholarship. 2014;46(5):377-88.

6. Lopez KD, Gerling GJ, Cary MP, Kanak MF. Cognitive work analysis to evaluate the problem of patient falls in an inpatient setting. J Am Med Inform Assoc. 2010;17(3):313-21.

7. Aiken LH, Clarke SP, Sloane DM, Sochalski J, Silber JH. Hospital nurse staffing and patient mortality, nurse burnout, and job dissatisfaction. Jama. 2002;288(16):1987-93.

8. Matsumoto A. Effective human resource management strategy for hospital nursing organizations. Manag Sci Lett. 2019;9(2):243-52.

9. Levine JM, Moreland RL, editors. Small groups: key readings. Psychology Press; 2008 Feb.:369.

10. Kang HJ, Gatling A, Kim J. The impact of supervisory support on organizational commitment, career satisfaction, and turnover intention for hospitality frontline employees. J Hum Resour Hospit Tourism. 2015;14(1):68-89.

11. Johansen ML, Cadmus E. Conflict management style, supportive work environments and the experience of work stress in emergency nurses. J Nurs Manag. 2016;24(2):211-8.

12. Cho SH, Kim YS, Yeon KN, You SJ, Lee ID. Effects of increasing nurse staffing on missed nursing care. Int Nurs Rev. 2015;62(2):267-74.

13. Dehghani M, Hayavie Haghighi MH, Tayary N, Khorami F. Nurses' organizational behavior and their quality of documentation. Journal of Nursing Education. 2015;3(4):68-80. [Persian]

14. Cropanzano R, Anthony EL, Daniels SR, Hall AV. Social exchange theory: A critical review with theoretical remedies. Acad Manag Annal. 2017;11(1):479-516.

15. Jeon BR, Noh YG. Impact of work-family conflict and social support on retention intention among married female nurses. J Digit Converg. 2018;16(10):261-70.

16. Labrague LJ, McEnroe-Petitte DM, Tsaras K, Cruz JP, Colet PC, Gloe DS. Organizational commitment and turnover intention among rural nurses in the Philippines: Implications for nursing management. Int J Nurs Sci. 2018;5(4):403-8.

17. Asadi Fakhr A, Asadi S. Investigation of the amount of stressors in operating room nurses. Pajouhan Scientific Journal. 2017;15(2):27-31. [Persian]

18. Hassankhani H, Mohajjel AA, Rahmani A, Mohammadpoorfard Z. Assessing Self-efficacy in Clinical Competence Among Nursing Students at Tabriz University of Medical Sciences. EDUCATIONAL DEVELOPMENT OF JUNDISHAPUR. 2015;6(2):107-14. [Persian]

19. Vera M, Martínez IM, Lorente L, Chambel MJ. The role of co-worker and supervisor support in the relationship between job autonomy and work engagement among Portuguese nurses: A multilevel study. Soc Indicat Res. 2016;126(3):1143-56.

20. Yaghoubi M, Ebrahimi Torki M, Salesi M, Ehsani-Chimeh E, Bahadori M. The Relationship between Teamwork and Missed Nursing Care: Case Study in a Military Hospital in Tehran. Journal Mil Med. 2019;21(1):63-72. [Persian]

21. Hernández-Cruz R, Moreno-Monsiváis MG, Cheverría-Rivera S, Díaz-Oviedo A. Factors influencing the missed nursing care in patients from a private hospital. Revista latino-americana de enfermagem. 2017;25:e2877.

22. Ball JE, Bruyneel L, Aiken LH, Sermeus W, Sloane DM, Rafferty AM, Lindqvist R, Tishelman C, Griffiths P, RN4Cast Consortium. Post-operative mortality, missed care and nurse staffing in nine countries: a cross-sectional study. Int J Nurs Stud. 2018;78:10-5.

23. Kossek EE, Pichler S, Bodner T, Hammer LB. Workplace social support and work-family conflict: A meta-analysis clarifying the influence of general and work-family-specific supervisor and organizational support. Person psychol. 2011;64(2):289-313.

24. McGilton KS, Hall LM, Wodchis WP, Petroz U. Supervisory support, job stress, and job satisfaction among long-term care nursing staff. JONA: J Nurs Administ. 2007;37(7/8):366-72.

25. Kalisch BJ, Landstrom G, Williams RA. Missed nursing care: errors of omission. Nursing outlook. 2009;57(1):3-9.

26. Khajooee R, Bagherian B, Dehghan M, Azizzadeh Forouzi M. Missed nursing care and its related factors from the points of view of nurses affiliated to Kerman University of Medical Sciences in 2017. Journal of hayat. 2019;25(1):11-24. [Persian]

27. Winsett RP, Rottet K, Schmitt A, Wathen E, Wilson D, Group MN. Medical surgical nurses describe missed nursing care tasks-Evaluating our work environment. Appl Nurs Res. 2016;32:128-33. 
28. Rezaee S, Baljani E, Feizi A. Missed Nursing Care in Educational, Private and Social Welfare Hospitals. Nursing And Midwifery Journal. 2019;17(4):300-8. [Persian]

29. Hammer LB, Kossek EE, Yragui NL, Bodner TE, Hanson GC. Development and validation of a multidimensional measure of family supportive supervisor behaviors (FSSB). Journal of management. 2009;35(4):837-56.

30. Kopp LR. The effects of perceived supervisor work-life support on employee work-life balance, job satisfaction, organizational commitment, and organizational citizenship behavior (Doctoral dissertation, University of Wisconsin--Stout) 2013.

31. Tuzun IK, Kalemci RA. Organizational and supervisory support in relation to employee turnover intentions. J Manag Psychol. 2012;27(5):518-34.

32. Galletta M, Portoghese I, Penna MP, Battistelli A, Saiani L. Turnover intention among Italian nurses: The moderating roles of supervisor support and organizational support. Nurs Health Sci. 2011;13(2):184-91.

33. Rezaee N, Ghajeh M. Social Support among Nurses at Iran University of Medical Sciences. Hayat. 2008;14(4):91-100. [Persian]

34. Gok S, Karatuna I, Karaca PO. The role of perceived supervisor support and organizational identification in job satisfaction. Proced Soc Behavl Sci. 2015;177:38-42.

35. Tuzun IK, Kalemci RA. Organizational and supervisory support in relation to employee turnover intentions. J Manag Psychol. 2012; 27(5): 518-34.

36. Barnett MD, Martin KJ, Garza CJ. Satisfaction with work-family balance mediates the relationship between workplace social support and depression among hospice nurses. J Nurs Scholarship. 2019;51(2):187-94.

37. Woodhead EL, Northrop L, Edelstein B. Stress, social support, and burnout among long-term care nursing staff. J Appl Gerontol. 2016;35(1):84-105..

38. Kalisch BJ, Lee KH. Missed nursing care: Magnet versus non-Magnet hospitals. Nursing outlook. 2012;60(5):e32-9.

39. Castner J, Wu YW, Dean-Baar S. Multi-level model of missed nursing care in the context of hospital merger. West J Nurs Res. 2015;37(4):441-61.

40. Lakey B, Orehek E. Relational regulation theory: a new approach to explain the link between perceived social support and mental health. Psychological review. 2011;118(3):482. 